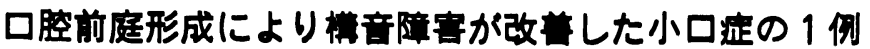

\author{
小松道正・糟谷政代・上田実・金田敏郎 \\ 鳥居䅉平*
}

\section{Microstomia with speech improvement by vestibuloplasty with fullthickness skin graft : Report of a case}

\author{
Michimasa Komatsu - Masayo Kasuya - Minoru Ueda \\ Toshio KANEDA - Shuhei TORI*
}

\begin{abstract}
A case of microstomia involved with a serious speech disturbance of a 19-year old female was reported. The patient visited Nagoya University Hospital on November 271982 complaining of a difficulty of mouth closing and speech disorders.

According to medical history, the patient contracted stomatitis at two years old and vestibular mucosa came to necrosis and lost. Vestibuloplasty has been carried out four times until now. From the initial examination, abundant scars were seen and vestibular sulcus of lower and upper lip were narrow. Selecting surgical method, we decided to carry out vestibuloplasty with fullthickness skin graft and free skin graft with the preserved subcutaneous vascular network to form the smooth movement of lips.

Under general anesthesia, scar tissue was removed and skin grafted. Eight days after the operation, all grafts were taken successfully. Deep vestibular sulcus was made, and then functional disturbance of lip was seldom observed.

We utilized the functions of articulation for an index in order to evaluate the postoperative restoration of lip function. The functions of articulation seemed to be a usefull index. At the 14 months examination following the surgery, there was no evidence of recurrence or other trouble.
\end{abstract}

Key words: microstomia, vestibuloplasty, improvement of speech

\section{緒亩}

小口症はまれに先天的に，あるいは種々の後天的原因 により発症する疾患である，本症はその病態の障害程度 にもよるが，単に審美的障害に留まらず，咀噃や構音障 害あるいは口腔清掃困難など，機能障害を合併すること

名古屋大学医学部口腔外科学諹座

（主任：金田敏郎数授）

* 名古屋大学医学部整形外科学講座 （主任：三浦降行救授）

Department of Oral Surgery, School of Medicine, Nagoya University (Chief: Prof. Toshio Kaneda)

* Department of Orthopedic Surgery, School of Medicine, Nagoya University (Chief: Prof. Takayuki Miura)

受付日：昭和61年 6 月16日
むあり，患者のもつ肉体的・精神的な苦悩の大きいこと が推察される.最近，われわれは 2 嵅時に䍜患した口内 炎が原因と思われる上下腔前庭部の激痕に対して，過去 数次にわたる形成手術を受けたのちの，著しい激痕拘縮 によって，檍音障害ならびに舌の構音時異常運動を認め た疫痕性小口症症例を治療する機会を得，全屏植皮手術 を施行した。 その結果, 舌の楼音時異常運動や口唇の機 能障害は改善し，患者自身す満足する結果を得たので， その概略を報告する。

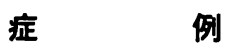
㭧 者 : 19瓷 女性 $\square$
初 診: 昭和 57 年11月四。.
主诉：発音障害, 口裂閉鎖困難.
家族暦：特記すべきことなし。
既往厢：2 歳時に原因不明の口内炎に罹患したほか 


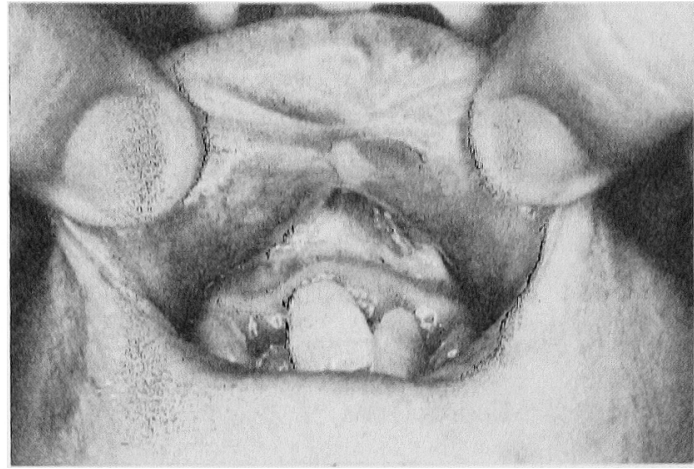

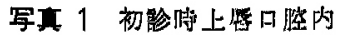

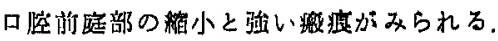

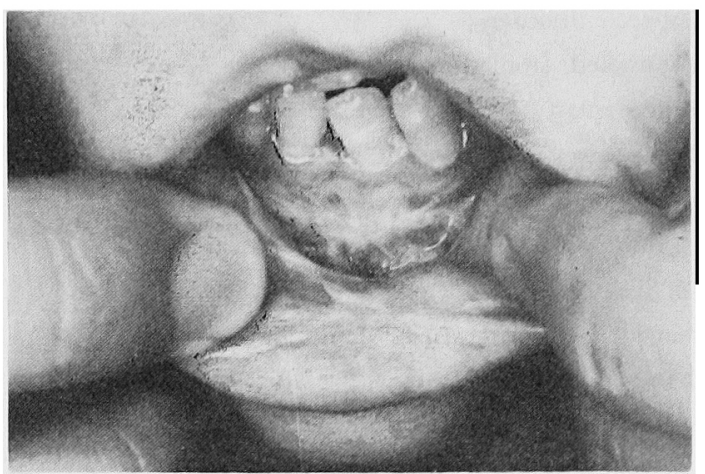

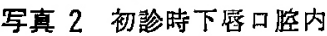

上唇と同様に口腔前庭部に強い, 廐痕拘樎が惩められ る。

は，特記事項はない，

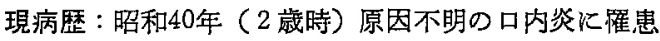
した後，上下唇，右口角部粘膜壊死により，前崡部口腔 前庭粘膜は脱落した，某病院にて右大腿部皮阐移植に上 る口唇形成術を受けた，昭和46年 (8 歳時) 頃より下樼 口腔前庭部粘膜は再び瘉着して，譏能障害程度は高度と なったため同病院にて，再度大腿部より採取した移植片 移植による口腔前庭执張術を受けた。 乙かし，その後増

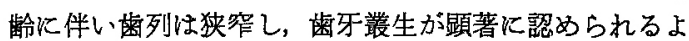
うになった，昭和49年（11歳時）より某歯科診撩所にて 矯正治療を開始したが，上唇粘膜㴔着が存在するため歯 列矯正治療上も障害となった，昭和54年 (16歳時) 同病 院にて右大腿部より移植片を採取し，口腔前庭拡張術 受けた。ささらに昭和55年 (17歳時) 下唇粘膜㾤着が認め られたので，再度口腔前庭拡張術を受けた。そその後口裂 閉鎖困難，公行・マ行等口唇音の構音障害，ストローに 上る吸叕困難，口笛不能などの障害が発現し，これらの 改善のために昭和 57 年 11 月 当科を受診した。

現 症 : 顔貌は左右対称であるが右口角部斜め下方に

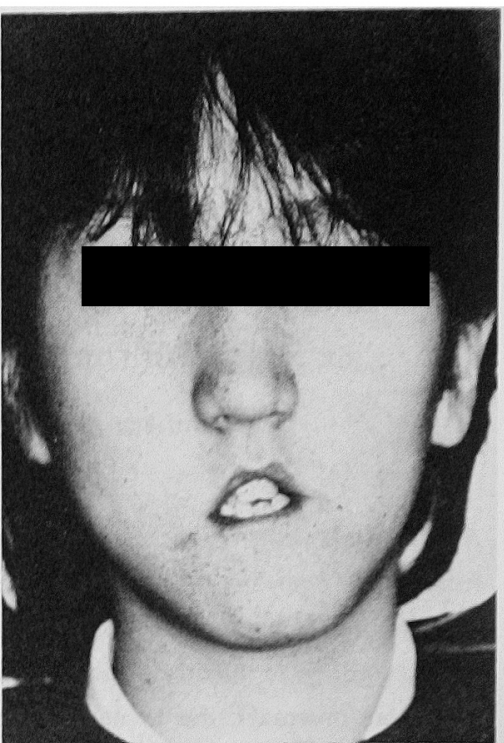

写南 3 初影時硕晛

口裂はいわ㓛る小口症を呈し，安腈暲 に閣鎖不全を示す

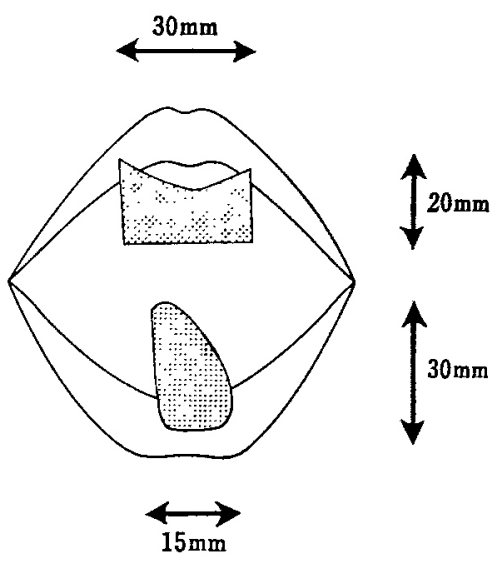

图 1 手微䘗式

濑图仕それぞれ口腔前庭部に生した raw surface の形状と大きさ

向かって，術後斿痕がみられた，下唇赤唇は薄く，正中 より左右口角にわたる般痕，さらに上下唇口腔前庭部に は著しい瘦痕拘縮が認められた（写真 $1 ， 2$ ）。裂はい わゆる小口症を呈し，安静時に上下唇は閉鎖不能である が，意識的に努力すれば閉鎖可能であった（写真ろ）. また，口唇を使用乙て発音するパ行・マ行・六行など， 口唇音の構音が困難であった，そのため患者は，これら の口唇音の構音点を上唇と, 舌を突出させてつくってい るため，歪み音となっていた，しかし，意識すると上下 


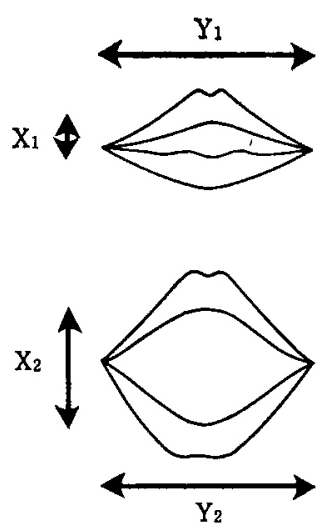

(術的・術後の比忟)

\begin{tabular}{|c|c|c|c|c|}
\hline & 徱访 & 術後 2 迥 & 術後14が」 \\
\hline \multirow{2}{*}{ 閉口时: } & $\mathrm{X}_{1 \mathrm{~mm}}$ & 12 & 12 & 12 \\
\hline & $Y_{1 \mathrm{~mm}}$ & 23 & 25 & 33 \\
\hline \multirow{2}{*}{ 開口凌 } & $\mathrm{X}_{2 \mathrm{~mm}}$ & 34 & 40 & 50 \\
\hline & $\mathrm{Y}_{2 \mathrm{~mm}}$ & 28 & 33 & 35 \\
\hline \multicolumn{2}{|c|}{$\begin{array}{c}\text { バ行，マ行， ハ行 } \\
\text { の発語明瞭度 }\end{array}$} & 不迤 & やや坫好 & 战好 \\
\hline
\end{tabular}

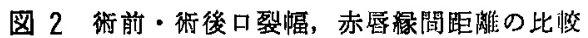

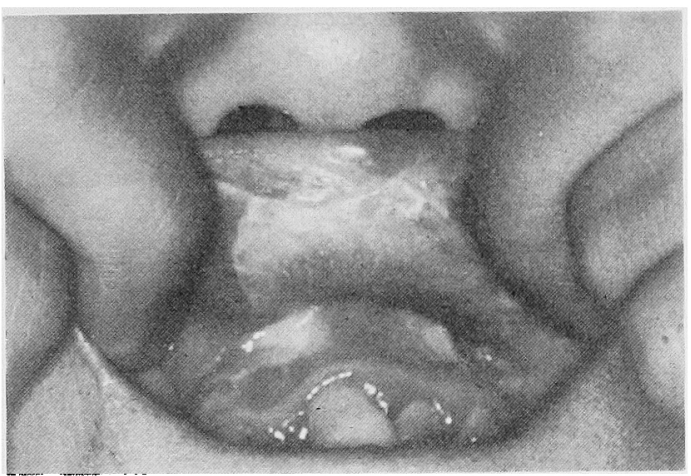

写真 4 路後14か上辰移植部

口膑前庭部は很前よりる深くなっている。

唇にての構音は可能であった，また，口腔内王を高める ために舌を突出させて，口裂閉鎖不全を補ら異常運動も 認められた。

初診時臨床診断：口唇変形症，小口症.

処置および経過：昭和 58 年 7 月 入入院. 諸検查の 後，症例の術式としてまず，瘦痕拘縮の解除が必須であ るため，拘縮㾝痕の切除を行い，生じる raw surface $に$ は全層植皮を行らこととした。すなわち，上唇に対して は鼠蹊部よりの全層植皮，下唇に対しては含皮下血管網 全層植皮を選択した，昭和58年 7 月—，気管内插管に よる GOE 麻䣲下にて, 上下唇拘縮部に切開を加え, 㾝 痕を切除すると上唇内面に $30 \times 20 \mathrm{~mm}$ ，下唇内面には $15 \times 30 \mathrm{~mm}$ の筋層に及ぶ粘膜欠損部を生じた（図 1 ）. 計画通り上唇には左圂蹊部よりの全層植皮片を，下唇に は右耳介後部よりの含皮下血管網全層植皮片をそれそれれ 移植し，タイオーバーにて王迫固定し，恵皮部は一次綘 縮した，術後 8 日でタイオーバーを除去したが，植皮片 はすへて生着した。術後 2 週目に術前と比較して, 開

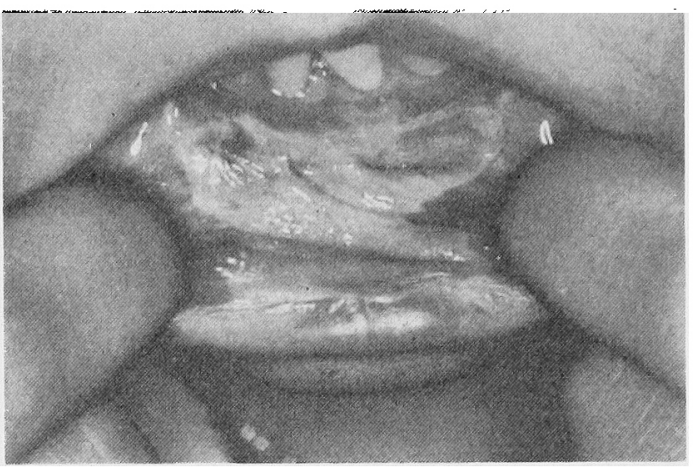

写真 5 衡後 14 出下唇移植部

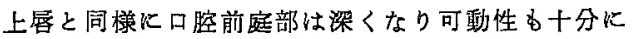
得られている。

口時上下赤唇縁間距離 $6 \mathrm{~mm}(t)$, 口角間距離 $5 \mathrm{~mm}$ (十), 閉口時口角間距離 $2 \mathrm{~mm}(+)$, 上下赤唇椂間距 離変化なしと, 開口運動での自由度に改善が羿められた （図 2)．また，開口時に口唇の形態は発症前のように丸 味を帯び，患者自身もあくび時に，口が術前よりる大き く開口することを自覚するよらになった，術後経過は良 好でパ行・マ行・バ行の口唇音は, 術前のように舌を 突出させずに両口唇のみで構音可能となった。また， blowing 時にも舌の突出が少なくなり，両口唇のみでも 可能となった，術後14か月を経過した現在，術前に認め られた舌, 口唇の機能障害は改善し，構音時の異常運動 む消失して，患者も満足する結果を得た（写真 4,5 ).

考察

口裂の長さが関係する口唇形態異常の 1 つである小口 症は, Freeman-Scheldon Syndrome ${ }^{1)}$ のよに先天的な 


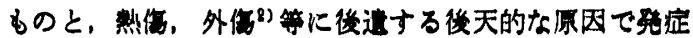

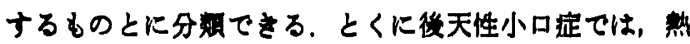

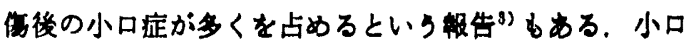

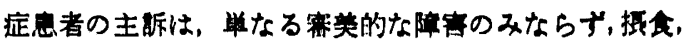

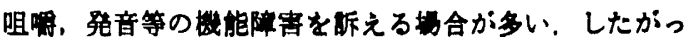

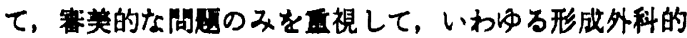
処但のみを行らと，血大な機能障害を後茺することがあ ろ. 口琌の抬大を目的とした Kajangian \& Converse 第 一法等を道用した手術例は多く報告されているい が，

ともナれば生理的機能回㪀については，なお゙きりにされ やナい.

今回われわれは模音檄能などの生理溨能の回得を主眼 とした，遊離皮庙移椬に上る口腔的庭払层手術を行い， 棈音障客や舌の異常荤鈔の改善をみることができた。意 者の椿音機能障害の原因は，2 藏時以降に行われた数回 の手術後激痕であるとは断定できないが，少なくとも言 語発達期で行われた手術が，上り運動性が向上したもの であったならば，顆回の手術は不必要となったものと推 湘される. 成長期に行われた遊離植皮片の大部分は払大 するので，植皮を行って差支えないといわれており，ま た，皮下脂肪の多少にかかわらず，植皮片の伸びの大小 は閔係ないと考えられている7．したがって，われわれ は拘樎をさけるため，口腔内への分層植皮は生着が不良 でも，全屏植皮が妥当と考えている．本症例で口唇音の 調音に際し, 舌の突出による代促性の異常運動がみられ た原因としては，過去の手術において比較的薄い分首植 皮が行われたため, 訹後拘縮が起こり上下唇の可動性か 不十分となったと推測された，そのため，本店例のよ5 な場合には，術後の収緶が少ない、8)全層植皮を採用すへ きであると考えられた。

術前, 術後の口列払大の增加は国 2 に示したが, 開口 時には両側唇交連間距離 $5 \mathrm{~mm}(+)$, 口裂高径 $6 \mathrm{~mm}$ （+）となり，口角部に切開を加えず，口腔前庭部の遊 離皮底移植のみで十分な口裂拡大が得られた。術後の再

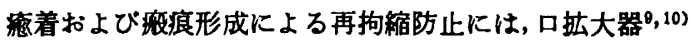
や床副子(1), R.H. McGOWAN らの使用した splint 12, 13) などの口裂維小防止装置を使用すれば，有効であったと 考えられる.今回われわれは特にこのよらな装固を採用 しなかったか，安静時口裂幅，口裂高径に関して，上條 の日本人成人平均値と较へると小さい(14)ことから，口裂 縮小防止装置は使用した方が，さらに良い結果が得られ たとも考えられた，口腔前庭部などのよ5に運動量の激 しい部位では, splint 等に用いて, 伸展力を外科処登後 に応用することも有効となろ5．さらに術後の正しい評 価のために, その生理機能障害の回復の程度を容覞的に 計る方法 (口周囲の筋電図, 口唇組織の弾性, 咀嚼率, 形態的唡查等) を利用する(5) ことが重要である. 今回わ れわれは, 術前, 術後の生理機能評価のために構音機能 検查を採用したが，本法も生理機能を評価するには有効
なカ法の1つと费えられた。

\section{結}

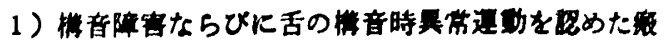

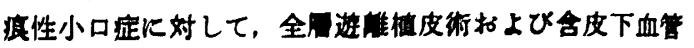

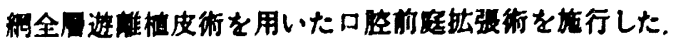

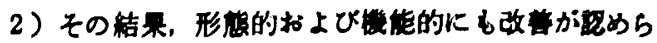

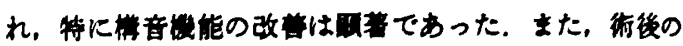

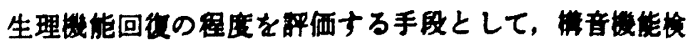
盁は有奻な万法の1つとなりらることがかかった。

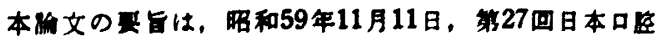

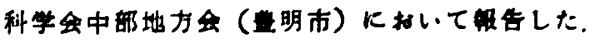

\section{引用文 触}

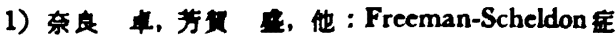

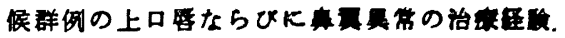
形成外科 21：281-288 1978.

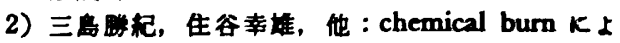
ク生した microstomia の19. 口科誌 21: 285-293 1972.

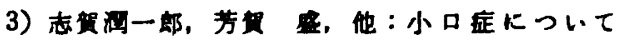
(抄). 形成外科 20:605 1977 .

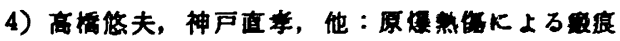

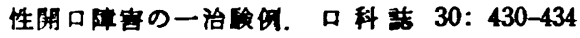
1981.

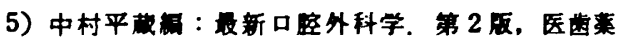
出版, 東京, 1974, 776面.

6）井原邦夫：痕性小口症の 1 症田，口科誥 27: 331-333 1978.

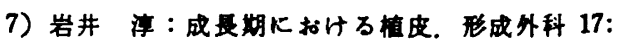
42-43 1974.

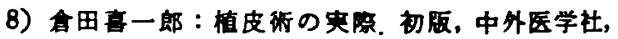
東京, 1974，160面。

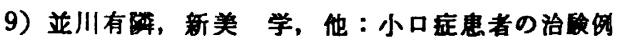
(抄). 形成外科 23: 791980 .

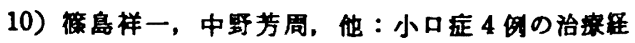
喻。科誌 33: 513-521 1984 .

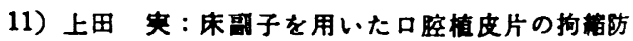

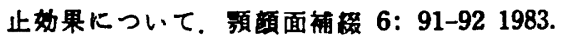

12) McGOWAN, R.H.: Prevention of Microstomia following Facial Burns. Brit dent J 149: 83-84 1980.

13) Naylor, W.P. and Manor, R.C.: Fabrication of a flexible prosthesis for the edentulous scleroderma patient with microstomia. J Prosthet Dent 50: 536-538 1983.

14）上保雍彦：因説口腰解剖学 5 . 第 5 服、フナト 一么社, 東京, 1976, 1211面.

15）高須 淳, 坂下宽信, 他: 小口症の一留）. 齿科医学 36: 2281973. 